\title{
From Shore to Shelf and Back Again
}

Corbett, I. B. ${ }^{1}$, McMillan, I.K. ${ }^{1}$

1. Mineral Resources Unit, De Beers Marine (Pty.) Ltd., P.O. Box 87, Cape Town 8000, South Africa

\section{Introduction}

The secondary diamond deposits on the West Coast of Southern Namibia have been mined extensively since 1908 (Corbett, 1996). During the 90 years since mining began, the global significance of the deposits remains unsurpassed. The development of the deep-water offshore mining industry is adding new information to aid in unravelling the complex interaction of systems and events responsible for their formation which resulted in a cycle of diamond transport from shore to shelf and back again.

Founded in 1983, De Beers Marine (Debmarine) is the largest diamond exploration and mining contractor on the West Coast of Southern Africa. The company operates a fleet of six vessels (with a seventh currently under conversion) capable of providing a full range of geophysical and geotechnical, sampling and mining services. Supported by specialised shore-based technical services in Mineral Resource Management and Engineering, production of just under half a million carats of diamonds a year from water depths that generally exceed $100 \mathrm{~m}$ off Southern Namibia. Extensive geophysical data acquisition across the entire shelf and continental slope within concessions held by Namdeb Diamond Corporation (Pty) Ltd has been integrated with deep seismic data from oil exploration surveys to construct a regional geological framework for understanding the development of the Southern Namibian continental shelf.

The regional offshore framework is being refined through integration with very high-resolution geophysical datasets acquired by Debmarine for orebody characterisation. Supplemented by a dense coverage of micro-palaeontological dating that has been extensively cross-referenced using radiometric techniques, detailed reconstruction of aspects of shelf geology is becoming possible. The fine-scale chronostratigraphic palaeogeography of the western continental margin has been traced over the past $150 \mathrm{My}$. from before continental break-up to the present-day.

The utilisation of the submersible "Jago" is bringing multi-disciplinary teams in to direct contact with the seafloor in deep-water concessions for the first time. For geologists involved, a new perspective is being obtained through the observation of mine faces and sample holes that can be relocated with ease due to the sophisticated positioning systems used, and natural seafloor exposures. Exciting new information about the physical characteristics of the orebodies on the shelf, their environments of deposition and the dynamics of the sedimentary systems that formed them will contribute to effective development of deep-water offshore mining into the future.

\section{Sequence Stratigraphic Framework}

The development of a geological framework for the continental margin of Southern Namibia has been hampered by the isolated nature of the sedimentary sequences exposed along the continental margin and the difficulty of dating key onshore sequences. It has therefore been particularly difficult to determine the role played by tectonics in driving post-Gondwana changes in fluvial system behaviour and sea-level. This has been resolved through the development of the offshore framework, which provides clear evidence for the persistent influence of subtle tectonics, and demonstrates that all things are relative - even on a so-called passive margin, depending upon the resolution of the data used. 
The application of sequence stratigraphic techniques has traditionally been most effectively applied to the study of continental shelf and slope rock successions. Attempts to apply the techniques to terrigenous clastic sequences have generally met with varied success, and much controversy. Large-scale diamond exploration and mining activities by De Beers both onshore and offshore in Southern Namibia has enabled development of detailed biostratigraphies for fluvial and aeolian sequences, although the presence of major unconformities does pose problems with correlation. Whilst the integration of the data is not straightforward, this rare opportunity created through the mining of secondary diamond deposits is leading to the identification of a high-resolution, tectonically-driven sequence stratigraphy that is probably based upon Milankovich cycles for all sequences preserved on the western continental margin. Each cycle represents unique uplift (erosion), Stillstand (non-deposition), subsidence (sedimentation) conditions which, coupled to the nature of the palaeoclimate and the type and quantity of terrestrial sediment supply, has led to stratigraphic succession that is singular to the western continental margin of Southern Africa.

\section{Orange River System - Canyon Throughput to Fan Delta Repository}

Sedimentological investigation of the spectacular Miocene and Plio-Pleistocene sequences exposed by onshore mining operations within the Orange River valley which introduced diamonds to Southern Namibia indicate that the deeply incised river operated as a canyon-type system through the Richtersveld Mountains. Under the flashy, high-energy conditions which prevailed, specific mechanisms control the development and preservation potential of diamond trapsites (Ward, et al., 1993; Jacob, et al., 1997, Allan and Frostick, 1997).

Incision of the system producing the Richtersveld Mountains contributed significant quantities of coarse clastics to the continental margin, which created ideal conditions for the extensive development of coarse clastic beaches that are characteristic of the high-energy coastal plain and continental shelf. The availability of coarse bedload undoubtedly contributed to the extreme erosional power of shoreface processes, resulting in the development of complex patterns of rugged terrain formed by gullies and cliffs on coastal platforms composed of Precambrian rocks (Murray et al., 1970; Apollus, 1995).

Observations with Jago revealed extremely coarse conglomeratic sequences exposed on the seafloor in an area of positive relief. Initial observations indicate that extensive erosion and shoreface incision has reworked the clastic sediment pile, effectively removing the fine-grained component to produce large quantities of very coarse gravel. The sediment pile probably represents a Pleistoceneaged(?) fan-delta complex, suggesting that the Orange system probably behaved similarly to model predictions (e.g. Wood, 1990) which would be consistent with the combined influence of shelf tectonics, changes in gradient at the transition from inner to middle shelf, and sea-level movement. Although no onshore examples are present in Southern Namibia, excellent fan-delta sequences are preserved along the present-day Skeleton Coast (e.g. Unjab River) in northern Central Namibia.

\section{High-Energy Shoreface Processes - Diamond Redistribution and Concentration}

Due to the high-energy coastal conditions, fan-delta sequences are probably reworked rapidly during shoreface incision on the west coast. Sedimentologists used Jago to observed extensive coarse gravel bodies interpreted to be the highly condensed product of marine reworking of coarse alluvial facies. The history of these gravel accumulations along palaeoshorelines is undoubtedly complex as multiple episodes of sediment introduction and reworking are probably represented. This has proved difficult to resolve onshore due to the highly destructive nature of these environments, which are unattractive habitats for marine organisms. Freshwater dissolution of biogenic carbonate to form calcrete palaeosols, has also effectively removed palaeontological 
evidence. Offshore sequences are palaeontologically richer, and provide an opportunity to better define the temporal relationships of the gravel bodies preserved on the shelf.

\section{Arid Zone Re-Entry}

During sub-aerial exposure of the continental shelf, sequences associated with palaeoshoreline development have been subjected to arid zone weathering and erosional processes (Corbett, 1993). Processes such as salt weathering are surprisingly capable of rapid and comprehensive destruction of coarse clastics to produce a finer-grained grit and small pebble fraction (Beetz, 1926; Corbett, 1989). Once released into the aeolian system, material (including diamonds) is susceptible to transport by aeolian processes. Field experiments using garnet demonstrate that "creep transport" (whereby grains are pushed forward in small increments by bombardment of smaller particles travelling in saltation at velocities which commonly exceed $70 \mathrm{~km} / \mathrm{hr}$ ) is particularly effective. Within a $20 \mathrm{~km}$ wide coastal tract within the Southern Namib, the wind direction is unimodal, and transport is dominantly northbound. Diamonds have been transported up the palaeoslope during sub-aerial shelf exposure into well-defined "aeolian transport corridors" (Corbett, 1989, 1990, 1993). At times, these corridors occupy south-north oriented endoreic basin features, where further potential exists to concentrate diamonds due to the presence of trapsites formed by rugged bedrock topography. Ephemeral stream systems within the basins commonly rework aeolian sediments containing diamond concentrations to produce characteristic diamond dispersal patterns (Corbett, 1989; 1993). The analysis of original prospecting data from 1908 to about 1920 reveals the subtlety of the aeolian system in sorting the diamonds. Repetition of this process and the removal of finegrained material due to unusual desiccation effects and aeolian abrasion further concentrated diamonds!

\section{References}

Allan, A and Frostick, L., 1997. Winnowing entrainment and matrix particle size: The behaviour of sand gravel mixtures in a laboratory flume. Abstr. $6^{\text {th }}$ Int. Conf. Fluvial Sedimentology, September 1997, Cape Town, p.5.

Apollus, L., 1995. The distribution of diamonds on a late Cainozoic gravel beach, southwestern Namibia. Unpubl. MSc. Thesis, Univ. Glasgow, pp. 170.

Beetz, W. 1926. Tertiärablagerungen der Küstenwüsternamib. In: Kaiser, E. (Ed.), Die Diamantenwüste Südwestafrikas, 2, 1-54. Dietrich Reimer (Ernst Vohsen), Berlin.

Corbett, I.B., 1989. The sedimentology of diamondiferous deflation deposits, Namibia. Unpubl. PhD, Univ. Cape Town, pp. 430.

Corbett, I.B., 1990. The modern and ancient pattern of sandflow through the Southern Namib deflation basin. In: Pye, K. and Lancaster, N (Eds.) 1993. Aeolian Sediments Ancient and Modern, Spec. Publ. 16, Int. Ass. Sedim.., Blackwell, Oxford.

Corbett, I.B., 1993. Observations on the formation of diamond placers by arid zone processes within the Sperrgebiet, Namibia. Mineral Exploration '93 Progr. With Abstr., Cape Town

Corbett, I.B., 1996, A review of diamondiferous marine deposits of western Southern Africa. Afr. Geosci. Rev., 3(2) pp. 157-174.

Murray, L.G., Joynt, R.H., O'Shea, D.O'C., Foster, R.W. and Kleinhan, L., 1970. The geological environment of some diamond deposits off the coast of South West Africa. In: The geology of the East Atlantic continental margin - 1 General Economic Papers. Inst. Geol. Sci. Rep. 70/13.

Ward, J.D., Barker, R and Corbett, I.B., 1993. Diamondiferous trapsites in Tertiary fluviatile deposits of the lower Orange River: Preliminary observations. Abs. Conf. Mining Investment in Namibia, March 1993, p. 20-21.

Wood, L.J., 1990, The effect of rate of base-level fluctuations on coastal plain-shelf-slope systems: An experimental modelling approach. Abstr. $13^{\text {th }}$ Int. Sedim. Congr., Nottingham, p. 605. 